\title{
Tinjauan Batas Usia Perkawinan Dalam Persfektif Psikologis dan Hukum Islam
}

\begin{tabular}{|c|c|}
\hline \multicolumn{2}{|c|}{$\begin{array}{c}\text { Ongky Alexander } \\
\text { STAI Bumi Silampari, Lubuklinggau, Sout Sumatera, Indonesia } \\
\text { ongkynhu@gmail.com }\end{array}$} \\
\hline & Abstrak \\
\hline $\begin{array}{l}\text { Article History } \\
\text { Received :20-02-2020 } \\
\text { Revised :22-02-2020 } \\
\text { Accepted :29-02-2020 } \\
\text { Keywords: } \\
\text { Psychological, } \\
\text { Marriage Age Limit, } \\
\text { Islamic Law, }\end{array}$ & $\begin{array}{l}\text { Psychologically, Human Age Limits include, First, } \\
\text { Childhood. Second, Adolescence, Third Adulthood, } \\
\text { Fourth, Old Age. At the Adult Stage is calculated at the } \\
\text { age of } 21 \text { years to about } 40 \text { years. Means that the age of } \\
\text { marriage aged } 19 \text { years does not include the adult } \\
\text { category. In general, marriage problems between men } \\
\text { and women are not seen from the age factor but age } \\
\text { limits affect the maturity of thinking and human } \\
\text { development psychologically. Especially in the case of } \\
\text { marriages that need to be considered is the age of } \\
\text { maturity, since the enactment of Law No. } 16 \text { of } 2019 \\
\text { concerning amendments to Law No. } 1 \text { of } 1974 \\
\text { concerning marriages, the current marriage age limit } \\
\text { between men and women is equal to the age of } 19 \text { years. } \\
\text { Of course this becomes a problem, because at that age } \\
\text { according to the psychological development of the ego } \\
\text { is still relatively high. So the cause of early divorce at } \\
\text { the age of about } 25 \text { years and over. }\end{array}$ \\
\hline
\end{tabular}

\section{Pendahuluan}

Perkembangan perilaku manusia tidak terlepas dari proses pematangan (maturity) atauperubahan bentuk fisik.Pematangan adalah proses pertumbuhan yang menyangkut penyempurnaan fungsi-fungsi tubuh secara alami sehingga mengakibatkan perubahan-perubahan dalam perilaku manusia. Selain itu, perkembangan sebagai perubahan psikofisis sebagai hasil dari proses pematangan fungsi-fungsi psikis dan fisis pada anak, yang dipengaruhi oleh faktor lingkungan dan proses belajar dalam waktu tertentu menuju kedewasaaan.( Kartono, Kartini, 1982 : 78) Menuju kedewasaan manusia tidak dilihat dari umur akan tetapi secara psikologi perkembangan manusia akan mengalami perubahan yang signifikan, mulai dari kedewasaan berfikir dan perubahan diri pada manusia itu sendiri, terutama dalam hal perkawinan. Untuk Membangun rumah tangga memang perlu persersiapan baik secara lahir maupun batin.

Pola perkembangan manusia itu relatif, hakikatnya perkembagan manusia itu tidak teratur. selain itu, fase perkembagan manusia akan mengalami perubahan setelah mengalami proses tahap perkembangan lainnya. Dalam Dictionary of Psychology tentangperkembagan manusia diantaranya perkembangan merupakan perubahan yang progresif dan terus menerus dalam sistem pembentukan organisme sejak lahir hingga mati, Perkembangan berarti tumbuh dan hidup, Perkembangan berarti pertumbuhan dalam bentuk dan penyatuan bagian-bagian yang bersifat jasmaniah kedalam bagian-bagian yang fungsional, Perkembangan berarti kematangan atau kemunculan pola dasar tingkah laku yang bukan hasil 
belajar. (J.P Chalin, $1972: 189$ ).

Pada umumnya, antara perempuan dan laki-laki mempunyai peranan yang berbeda, pada laki-laki mencari nafkah,dan giat bekerja. Sedangkan perempuan mengurus rumah tangga, aktif di rumah dan lebih menerima keadaan. Perilakunya pun berbeda, pria lebih kasar, sedangkan perempuan lebih halus.Adapun Perbedaan sifat laki-laki dan perempuaan diantaranya maskulin (yang biasa terdapat pada laki-laki, tegas, rasional, cepat membuat keputusan, dan lain-lain), Feminin (yang biasa terdapat pada perempuan : lemah lembut, emosional, lebih suka mengikuti keputusan, dan lain-lain), Androgin (pria atau perempuan yang mempunyai sifat maskulin maupun feminine yang sama kuat), Tak tergolongkan (dalam tes gender menunjukkan skor maskulin dan feminin yang sama-sama rendah).

Dalam hal Batas Usia perkawinan secara tidak langsung mempengaruhi perkembangan dan kedewasaan kemantangan berpikir manusia, dalam psikologis usia manusia di antaranya dewasa awal (21-40 tahun) tahap ini adalah masa penyesuaian terhadap pola pengembangan diri, kemandirian, serta mempunyai tujuan dan harapan yang tinggi. Batasan usia ini di tuntut untuk membina rumah tangga, harapannya mempunyai anak, mengurus keluarga, membuka karier serta mencapai keberhasilan, Dewasa menengah (40-60 tahun), tahapan dewasa menengah merupakan masa transisi, masa menyesuiakan kembali, masa keseimbangan (equilibrium-disequilibrium) Masa yang ditakuti karena mendekati masa tua. perempuan akan merasa kekhawatiran terkait masalah reproduksi. Masa ini adalah kekhawatiran masa berbahaya bagi pria dan wanita.

Masalah kedewasaan merupakan masalah yang penting, khususnya dalam lembaga perkawinan. Karena mempengaruhi terhadap keberhasilan rumah tangga. Seseorang yang telah dewasa, fisik, dan mental, belum bisa membina dan mendirikan rumah tangga yang sempurna, terutama orang muda yang belum dewasa. Tanpa kedewasaan, permasalahan yang timbul dalam rumah tangga akan disikapi dengan emosi. Kunci perkawinan yang sukses, dituntut adanya kedewasaan dan kematangan dari segi fisik mental dan emosional bagi calon suami dan istri yang hendak melangsungkan perkawinan. (Karim Helmi, 2000 :76) Selain itu, masalah kemantangan fisik, mental dan emosional dari masing-masing pasangan akan dapat menghasilkan keturunan yang baik dan sehat. tujuannya untuk mewujudkan perkawinan secara baik. Karena salah satu faktor penyebab terjadinya perceraian disebabkan ketidakmantangan jiwa, emosi dan fisik antara pasangan suami dan istri.

Berdasarkan latar belakang diatas, penulis ingin mengkaji bagaimana konsep batas usia menikah menurut psikologis dan bagaimana konsep batas usia menikah menurut Hukum Islam dengan masalah bagaimana konsep batas usia dewasa menikah dalam persfektif Psikologis?Bagaimana konsep batas usia dewasa menikah dalam persfektif HukumIslam?

\section{Metode penelitian}

Metode peneltian ini menggunakan penelitian deskriptif, penelitian ini bersifat evaluatif menilai suatu kegiatan atau program sesuai apa yang diharapkan. Menganalis UU No 16 Tahun 2019 Pasal 1 Ayat 7 tentang Perubahan UU atas UU No 11974 TentangPerkawinan) Penelitian ini menggunakan pendekatan konsep perkembangan tentang batas usia menikah. Dalam persfektif psikologis. 


\section{Pembahasan}

\section{Konsep Batas Usia Nikah dalam Persfektif Psikologis}

Perkawinan adalah perjanjian suci membentuk keluarga antara seorang lakilaki dengan seorang perempuan. Salah satu tujuan perkawinan adalah untuk membentuk keluarga yang bahagia dan kekal. Bagi Pasangan yang ingin menikah perluperencanaan yang matang, terutama masalah pengelolaan keuangan, tempat tinggal dan sebagainya. Sehingga rumah tangganya tidak goyang ketika menghadapi permasalahan keluarga. Dalam psikologi istilah dewasa disyaratkan dengan kematangan, baik dengan kematangan koqnotif, efektif maupun psikomornya, yang lebih mengacu pada sikap bertanggunjawab. Disamping itu, Secara psikogis bahwa usia terbaik menikah adalah bagi seorang perempuan adalah usia 19 sampai 25 tahun, sedangkan bagi seorang laki-laki usia 20 sampai 25 tahun, usia tersebut baik untuk menikah, memulai kehidupan rumah tangga serta baik untuk mengasuh anak. sehingga Kesiapaan Mental untuk menikah seorang yang siap menikah menanggung setiap resiko yang muncul selama hidup dalam pernikahan. misalnya masalah ekonomi, pengasuhan anak, dan sebagainya. (Diane E. Papalia dan Silly,2002 :45).

Dalam psikologi perkembangan, hakikatnya memang perkembangan tidak tampak teratur, bisa saja perkembangan tidak maju atau mundur menurut usia, akan tetapi, pada dasarnya perkembangan itu tidak meloncat-loncat. barangkali menyangkut dimensi moral atau penemuan diri. sehingga perkembangan itu harus dikuasai dulu sebelum menginjak proses tahap berikutnya. Berkaitan juga dengan batasan usia bagi pasangan yang ingin menikah, permasalahan kedewasaan bukan dilihat dari segi usia, akan tetapi usia seseorang mempengaruhi dalam perkembangannya. Sehingga bagi pasangan yang ingin menikah harus diperhatikan masalah umur dan kedewasaan. Sehingga perkawinannya tetap utuh dan langgeng.

Salah satu faktor terjadi perceraian bagi pasangan suami istri karena kurang kedewasaan dalam menghadapi permasalahan keluarga. Menurut Alissa Wahid, mengatakan saat ini makin banyak perkawinan yang umurnya di bawah lima tahun karena sangat mudah bagi pasangan suami istri untuk bercerai, bahkan, yang banyak mengggugat cerai justru adalah istrinya. artinya kedewasaan usia mesti dipertimbangakan bagi pasangan yang ingin menikah. Masalah usia bagi pasangan yang ingin menikah memang tidak menjadi permasalah, akan tetapi bagi pasangan setelah menikah usia tersebutakan terlihat sifat dan karekter aslinya. Karena usia seseorang secara tidak langusng mempengaruhi sifat dan kareketernya dan juga pengaruh dari keluarganya. Ketika usia tersebut belum dewasa biasanya mudah tersinggung, mudah cemburu,tertutup dan sebagianya. serta tidak mampu mengendalikan emosinya.

Selain itu, masalah reproduksi usia juga mempengaruhi bagi perempuan belum cukup umur atau dewasa. biasanya perempuan rentan emosi dan tidak stabil sehingga mempengaruhi terhadap bayinya. kehamilan yang baik tentu akan menghasilkan anak yang baik juga. Begitu sebaliknya ketika reproduksitidak sehat tentu akan menjadi buruk bahkan fatal bagi ibunya dan bayinya. 
Perkembangan kepribadian seseorang dilihat bahwa faktor genetika dan pematangan mempunyai peranan yang penting dalam perkembangan kepribadian seseorang. Mulai dari proses genetik dan pematangan melekat pada jiwa manusia setiap waktu pada kehidupan seorang secara individual. Permasalahan yang terjadi di dalam kehidupan di usia muda biasanya masalah kebutuhan ekonomi. khususnya perempuan yang menikah muda harus menghadapi permasalahan lingkungan dan sosial. sehingga mereka harus mampu bertahan utuk mengatasi stress dan tekanan yang muncul dalam kehidupan keluarganya. Sehinggga Dampak yang terjadi akibat menikah di usia muda diantaraya,terjadinya kekerasan dalam rumah tangga, peluang kematian ibu tinggi, dan hak kesehatan reproduksi rendah.( BKKBN : 2011).

Perkawinan di usia muda juga berpengaruh pada ketidaksiapan keluarga dalam mengemban untuk mengasuh anak. Biasanya peran perempuan yang menikah muda belum cukup memiliki kesiapan dalam menjalankan fungsi pengasuhan anak. Selain itu, kematangan usia diduga salah satu faktor penyebab, belum mampu bagi perempuan muda dalam mengasuh anak padahal fungsi pengasuhan sangat penting pada akhirnya nanti akan berdampak pada kualiatas anak. (Tsania, $2014: 78$ )

1. The physiological needs (kebutuhan fisiologis), jenis kebutuhan ini berhubungan dengan pemenuhan kebutuhan dasar semua manusia diantaranya : makan, minum, menghirup udara, istirahat, menghindari rasa sakit, seks, dan lain-lain.

2. The safety needs (kebutuhan rasa aman), jenis kebutuhan ini akan muncul jika kebutuhan fisiologis telah terpenuhi secara layak, dan yang termasuk kebutuhan jenis ini, adalah kebutuhan terhadap perlindungan, keamanan, ketertiban, hukum, stabilitas, dan lain-lain. Kebutuhan ini menjadi kebutuhan yang meningkat dan jika tidak terpenuhi, maka akan timbul rasa cemas atau rasa takut yang dapat menghambat pemenuhan kebutuhan lainnya.

3. The belongingness and love needs (kebutuhan akan rasa memiliki dan kasih sayang), jenis kebutuhan ini muncul jika kedua jenis kebutuhan di atas terpenuhi. Kebutuhan ini terlihat ketika seseorang berusaha untuk mencari dan mendapatkan teman, kekasih, keturunan (anak), bahkan keinginan untuk menjadi bagian dari suatu komunitas tertentu.

4. The esteem needs (kebutuhan akan harga diri), terbagi dua jenis, yaitu: lower one, kebutuhan yang berkaitan dengan status, atensi, dan reputasi, serta higher one kebutuhan yang berkaitan dengan kepercayaan diri, kompetensi, prestasi, kemandirian, dan kebebasan.

5. The need for self-actualization (kebutuhan terhadap aktualisasi diri), jenis kebutuhan ini berkaitan erat dengan keinginan untuk mewujudkan dan mengembangkan potensi diri. Kepribadian dapat mencapai peringkat teratas jika kebutuhan-kebutuhan primer ini banyak mengalami interaksi satu dengan yang lain, dan dengan aktualisasi diri seseorang akan dapat memanfaatkan faktor potensialnya secara sempurna.

\section{Konsep Batas Usian Nikah dalam Persfektif Hukum Islam}

Tujuan perkawinan dalam Islam adalah untuk memenuhi tuntutan naluri hidup manusia, hubungan antara laki-laki dan perempuan dalam rangka mewujudkan kebahagian keluarga sesuai ajaran Allah dan Rasulnya. Perkawinan 
merupakan tuntutan naluri manusia untuk mendapatkan (zuriyat) keturunan dan memperoleh ketenangan hidup serta menumbuhkan rasa kasih sayang. Disamping itu, prinsip perkawinan yang dibawa oleh rosulllah S.A.W secara tidak langsung untuk menata kehidupan manusia diantaranya :

a. Rub al-ibadat, menata hubungan manusia sebagai mahluk dengan khaliknya

b. Rub al-muamalat, menata hubungan manusia dengan sesesamanya untuk memenuhi hajat hidupnya.

c. Rub al-munakahat, menata hubungan manusia dengan keluarga

d. Rub al-jinayat, adalah menata hidup untuk menjaga keaman pribadi pengamannya dengan sesuatu tertib pergaulan yang menjamin ketentramannya.( Ali Yafie, $1982: 1$ ).

Di dalam Islam tidak diatur secara sfesifik batasan minuman usia menikah baik di dalam al-Qur'an maupun Hadist, syaratnya mampu untuk menikah sudah baliqh dan berakal, dan mampu membedakan mana yang baik dan buruk.Di samping itu, Kedewasaaan seseorang dapat dilihat dari tanda-tanda yang nampak dalam dirinya, misalkan : Keluar mani atau sudah bermimpi bagi laki-laki dan menstruasi bagi perempuan. Beberapa pendapat Imam Mazhab terkait masalah batasan kedewasaan seseorang:

a. Menurut Mazhab Syafiiyah dan Hanabilah, Menjelaskan bahwa masa dewasa itu dimulai umur 15 tahun, batasan kedewasaan itu dimulai dengan datangnya haid bagi perempuan dan mimpi bagi anak laki-laki. tanda-tanda tersebut tidak sama datangnya pada setiap orang. sehingga kategori kedewasaan itu dibatasi dengan standar umur. Selain itu, Kedewasaan lakilaki dan perempuan itu ditentukan oleh akal. Karena dengan akal terjadiya Taklif dan dengan akal pula adanya beban hukum.

b. Menurut Abu Hanifah bahwa kedewasaan itu datangnya umur 19 Tahun bagi laki-laki dan 17 Tahun bagi perempuan

c. Menurut Imam Malik menetapkan bahwa kedewasaan itu dimulai umur 18 Tahun baik bagi perempuan atau laki-laki. (Abd al-rahman al-Jaziri, 2003 : $315)$.

Hubungannya dengan Masalah usia bisa dilihat dari perilaku atau tabiat seseorang secara lahiriyah maupun batiniyah,contohnya : bekerja dengan baik, tidak mudah menyerah ketika mengalami kesulitan, berani menghadapi halangan dan rintangan. Mempunyai cita-cita yang tinggi dan optimis bahwa segala sesuau dapat di rubah. Sikap ini untuk proses mengukur kedewasaan seseorang. Sebagaimana Firman Allah dalam Surat An-Nur : 32.

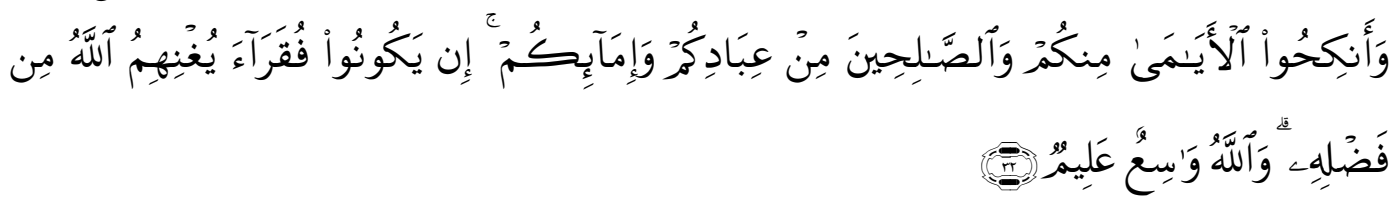

Artinya : Dan kawinkanlah orang-orang yang sendirian diantara kamu, dan orang-orang yang layak (berkawin) dari hamba-hamba sahayamu yang lelaki dan haba-hamba sahayamu yang perempuan, jika mereka miskin, Allah akan menampukan mereka dengan karunianya, dan Allah Maha Luas (pemberiannya) lagi Maha Mengetahui. 
Terkait penjelasan Ayat diatas menurut Tafsir Ibnu Katsir (al-Imam Abi Fada Al-HafisIbnu Katsir al-Damasqy, 2004 : 89).dijelaskan bahwa ayat tersebut sebuah perintah bagi laki-laki maupun perempuan yang sudah mampu untuk menikah. Sedangkan Tafsir al-Maraghilmenjelaskan bagi laki-laki maupun perempuan yang sudah mampu untuk menikah dan menjalankan hak-hak suami istri serta mempunyai harta dan sebagainya. SebagaimanaFirman Allah dalam Surat An-Nisa':6.

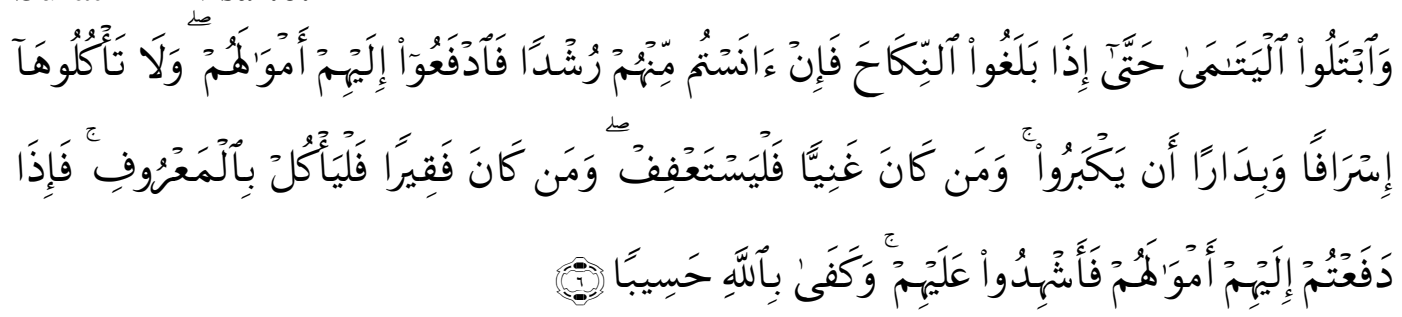

Artinya : Dan ujilah anak yatim itu sampai mereka cukup umur untuk kawin, kemudian jika menurut pendapatmu mereka telah cerdas (pandai memelihara harta), maka serahkanlah kepada mereka harta-hartnya dan janganlah kamu makan anak yatim lebih dari batas kepatutan dan janganlah kamu tergesa-gesa membelajankannya sebelum mereka dewasa. Barangsiapa diantara pemelihara itu mampu, maka hendaklah ia menahan diri dari memakan harta anak yatim itu, dan barang siapa miskin, maka bolehlah ia makan harta anak itu menurut yang patut. Kemudiian apabila kamu menyerahkan harta kepada mereka. Maka hendaklah kamu adakan saksi-saksi (tentang penyerahan itu) bagi mereka. Dan cukuplah Allah sebagai pengawas atas persaksian.

Terkait penjelasan ayat tersebut dalam Tafsir Al_Maraghi Abu Bakar Ibnu Umar, (Thabaqat al-Syafi'iyyah al-Kubra, 1994 :.48) dijelaskan bahwa apabila laki-laki dan perempuan mengerti dengan baik cara menggunakan harta dengan membelanjakannya disebut Rusdhan, sedangkan Baligh Nikah adalah jika umur telah siap menikah. sedangkan bagi laki-laki maupun perempuan yang belum dewasa tidak boleh dibebani permasalahan-permasalahan tertentu. Selain itu, menurut Rasyid Ridha, makna Baligh Nikah, adalah menunjukan bahwa usia bagi laki-laki maupun perempuan untuk menikah yaitu sudah bermimpi, pada umur tersebut seseorang telah dapat melahirkan anak dan memberikan keturunan(zuriyat) sehingga tergerak hatinya untuk menikah. (LTN PBNU, 2010 :9) 


\section{Simpulan}

Bahwa secara psikologis usia ideal untuk menikah usia 21 Tahun bagi laki-laki-laki maupun perempuan. Dalam Islam tidak diatur secara sfesifik batasan minuman usia menikah baik di dalam al-Qur'an maupun Hadist, syaratnya mampu untuk menikah sudah baliqh dan berakal. Bahwa sejak berlakunya UU No 16 tahun 2019 tentang perubahan atas UU No 1 tahun 1974 tentang perkawinan bahwa usia menikah 19 Tahun bagi laki-laki maupun perempuan. Pemerintah untuk mengkaji lagi UU No 16 tahun 2019 tentang perubahan atas UU No 1 tahun 1974 tentang perkawinan terkait batas usia menikah, karena usia 19 Tahun tersebut secara psikologi belum kategori dewasa untuk menikah. Bahwa salah satu penyebab terjadinya perceraian karena usia belum dewasa ketika menyelesaikan persoalan rumah tangga. 


\section{DAFTAR PUSTAKA}

Ali Yafie, 1982. Pandangan Islam Terhadap Kependudukan dan Hukum Keluarga, Jakarta: Lembaga Kemaslahatan Keluarga Nahdhatul Ulama dan BBKBN.

Al-Imam Abi Fada Al-Hafis Ibnu Katsir al-Damasqy, 2004. Tafsir Ibnu Katsir, (Bayrut :Dar al-Kutub al-'Illmiyyah.

Abu Bakar Ibnu Umar, Thabaqat al-Syafi'iyyah al-Kubra, Bayrut :Alam alKutb,t.t

Abd al-rahman al-Jaziri, 2003. Kitab al-FiqhAla' Madzahib al-Arba'ah, Bayrut :dar al-Kutub al-Ilmiyyah.

Badan Koordinasi Keluarga Berencana Nasional. (BKKBN) 2011. Pernikahan dini pada beberapa provinsi di Indonesia: dampak overpopulation, akar masalah dan peran kelembagaan di daerah. Jakarta (ID): BKKBN.

Dariyo, Agoes. Psikologi Perkembangan Remaja. 2004. Bogor: Ghalia Indonesia

Diane E. Papalia dan Silly 2002. Wendkos Olds (Adhim).

J.P Chalin dalam Dictionary Of Psychology 1972. PerkembaganManusia, Fifth Printing, Newyork: Dell Publshing.

Karim Helmi, 1996. Kedewasaan Untuk Menikah, dalam Chuzaimah T. Yanggo dan Hafiz Anshary. Problematika Hukum Islam Kontemporer, Jakarta: Pustaka Firdaus.

Mark E. Cammack, 2010. Hukum Islam. Jurnal. Vol .38 LTN PBNU, Solusi Probelematika Aktual Hukum Islam, Keputusan Muktamar Munas dan Konbes Nahdhatul Ulama, Surabaya :Khalista.

Tsania, N. 2014. Karakteristik Keluarga, Kesiapan Menikah Istri dan Perkembangan Anak Usia 3-5 tahun., Bogor: Institut Pertanian Bogor.

Yusdani, 2015. Muпијu Fikih Keluarga Proresif, Yogyakarta: Kaukaba Dipantara,

Kartono, Kartini, 1982. Psikologi Anak, Bandung: Alumni.

Undang-Undang Nomor 1 Tahun 1974 tentang Perkawinan 